\title{
REVIEW OF THE SUSTAINABLE BUILT ENVIRONMENT IN 1998-2015
}

\author{
Ieva UBARTE, Oleg KAPLINSKI \\ ${ }^{a}$ Research Institute of Smart Building Technologies, Faculty of Civil Engineering, \\ Vilnius Gediminas Technical University, Sauletekio al. 11, LT-10223, Vilnius, Lithuania \\ ${ }^{b}$ Faculty of Architecture, Poznań University of Technology, Nieszawska 13C, 60-965 Poznań, Poland
}

Received 22 April 2016; accepted 10 May 2016

\begin{abstract}
A city is a complex physical and social phenomenon that is under constant development and undergoes quantitative and qualitative changes. The welfare of the whole society depends on the sustainability of the built environment. The article presents a review of the literature on the sustainable built environment, which was made on the basis of the Thomson Reuters Web of Science Core Collection database. The analysed articles were published between 1998 and 2015. The analysis of the number of publications was made according to years of publication, countries, research areas and the Web of Science categories. 31 article and review document type were selected for a detailed analysis by three key Web of Science categories: environmental science, environmental studies, and construction and building technology.
\end{abstract}

Keywords: sustainable built environment, environmental science, environmental studies, construction and building technology, literature review.

\section{Introduction}

The built environment - human-modified places such as homes, schools, workplaces, parks, industrial areas, farms, roads and highways - is our most important habitat (Srinivasan et al. 2003). It includes all of the physical parts of where we live and work (e.g., homes, buildings, streets, open spaces, and infrastructure) (Stanhope 2012). In achieving sustainable development, the built industry is a key player (De Meester et al. 2009) because the built environment is responsible for the significant use of final energy $(62 \%)$ and is a major source of greenhouse gas emissions (55\%) (Anderson et al. 2015).

A constructive interplay between three main components (the environment, economics and society) is the backbone of the concept of the sustainable development (Štreimikienè et al. 2014). A city is a complex physical and social phenomenon that is under constant development. It undergoes quantitative and qualitative changes. The welfare of the entire society depends on the sustainability of the urban development (Zavadskas et al. 2007). The sustainable development is becoming a dominating principle in planning a new and compact format of a city residential area. The current concept of impossibility to live in such residential areas urges us to reconsider our present practice of urban planning. Acceptance of new and innovative ideas in the process of urban planning is a new challenge for the development of the sustainable built environment (Zavadskas, Antucheviciene 2006; Viteikiene, Zavadskas 2007; Kaklauskas et al. 2015).

The dimension of the problem under consideration grows when life cycle analysis needs are taken into consideration. Examples of presenting this problem area from the viewpoint of life cycle have been presented in (Kaklauskas et al. 2015; Dziadosz et al. 2015).

An important issue is the search for an adequate set of instruments to solve the environment - eco-

Corresponding author:

O. Kaplinski E-mail: oleg.kaplinski@put.poznan.pl 
nomics - society triad (c.f. Antucheviciene et al. 2015; Kaklauskas, Zavadskas 2012; Kaklauskas et al. 2014; Kapliński, Tupenaite 2011). One of the methods under consideration is (MCDA) - the multi-criteria decision method.

Researchers use various MCDM methods to analyse the sustainable built environment. Zavadskas et al. (2014) gave an overview of MCDM/MADM methods, which demonstrated that $9.26 \%$ of MCDM methods had been used in the environmental science, in the area of ecology (mostly in relation to energy fuels, where $16.67 \%$ of the methods had been used) (Zavadskas et al. 2014). Based on the review by Zavadskas et al. (2016), regarding the application of hybrid multiple-criteria decision-making methods in engineering, the most popular methodological approaches were combinations of crisp AHP with TOPSIS or ANP with TOPSIS, as well as their combinations in a fuzzy environment. In the analysis of issues pertaining to sustainable energy and renewable energy, the most popular methods were AHP, VIKOR and ANP, TOPSIS and PROMETHEE, etc. as well as integrated methods (Mardani et al. 2015; Kaplinski et al. 2014).

This article presents a review of the sustainable built environment in 1998-2015, made on the basis of the Web of Science Core Collection database. Aiming to develop a healthy and safe environment, based on the holistic approach in the face of the urbanisation issues, it is especially important to focus on the sustainable development with the help of the most up-todate methodologies, systems and solutions offered by researchers.

\section{Research methodology}

In this paper, the literature related to the sustainable built environment has been reviewed comprehensively on the basis of papers referred in the Thomson Reuters Web of Science Core Collection database. Following a methodological analysis (Fig. 1), the analysis focused on articles published before 11 February 2016.

The review must be preceeded by the following remark. As foreign authors use different terms, namely "criterion" and "indicator", the review was made using the following combinations:

- sustainable built environment + criteria;

- sustainable built environment + indicators.

The presented research attempts to answer the following questions: (1) How are the papers distributed

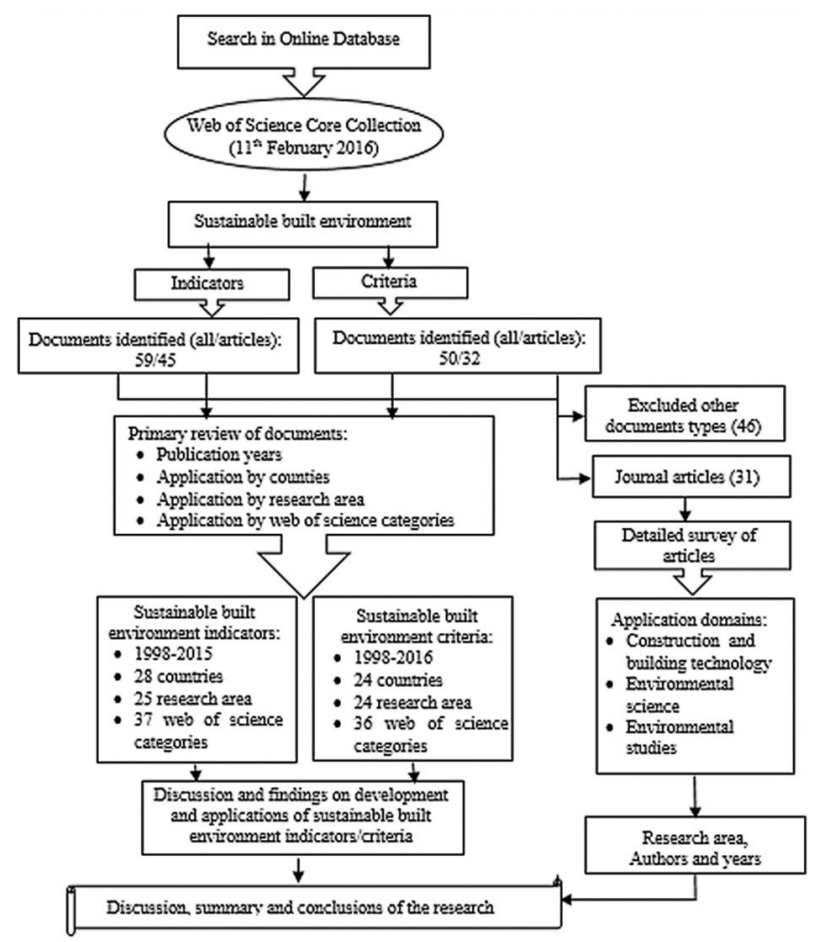

Fig. 1. Procedure of the research

by the period of publishing? (2) How are the papers distributed by country? (3) In what research areas the sustainable built environment was applied? (4) How were the papers distributed by the Web of Science categories?

The assumed research methodology had been verified in the research (Zavadskas et al. 2015a, 2015b).

\section{Analysis of publications}

\subsection{Number of publications: by years and countries}

The Web of Science Core Collection database (up to 11 February 2016) had 50 publications with the term "criterion" that covered all of the document types, including research articles, reviews, proceedings papers, and other documents. The analysis of the search using the keyword "indicator" resulted in 59 publications that covered all of the document types, including research articles, reviews, proceedings papers, and other documents (Table 1).

The analysis of articles by years (1998-2015) revealed that, compared to 2014, 2015 saw $57.13 \%$ more of articles on criteria of the sustainable built environment and $66.67 \%$ more of articles on indicators of the sustainable built environment. The comparison is presented in the graph in Figure 2. Besides, 2016 already has one article on criteria of the sustainable built en- 
Table 1. Publications on the topic of the sustainable built environment in the Web of Science database

\begin{tabular}{|c|c|}
\hline Publications on criteria of the sustainable built environment & Number of publications \\
\hline All & 59 \\
\hline Articles & 45 \\
\hline Publications on indicators of the sustainable built environment & \\
\hline All & 50 \\
\hline Articles & 32 \\
\hline
\end{tabular}

vironment. The comparison of the search results revealed that $14.03 \%$ more articles were publicised on indicators of the sustainable built environment than on criteria of the sustainable built environment (i.e. 57 and 49 articles, respectively).

Most articles on the sustainable built environment using the keyword "criterion" originated from England. They comprise $15.1 \%$ of all articles (i.e. 8 out of 53 ). 10 articles of 71 on the sustainable built environment used the keyword "indicator"; they originated from the USA and amounted to $14.1 \%$. The comparative graph is presented in Figure 3.

\subsection{Number of publications by a research area and the Web of Science categories}

Publications on the sustainable built environment from the Web of Science Core Collection database were also analysed by research area and the Web of Science categories.

The analysis by research areas has revealed that most research efforts are concentrated on areas of construction building technologies, engineering and environmental science ecology (Fig. 4). A similar trend held true in the analysis of the Web of Science categories.

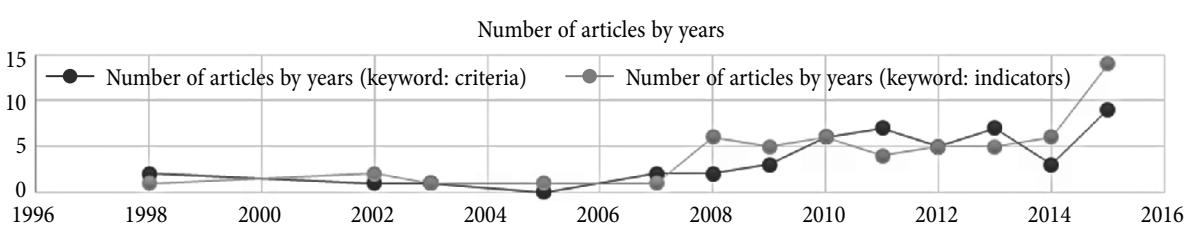

Fig. 2. Review of articles on the sustainable built environment by years using the keywords "criterion" and "indicator"

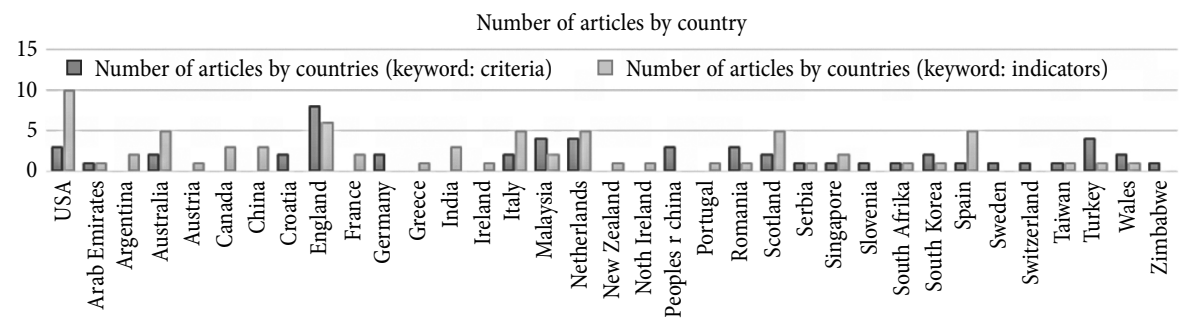

Fig. 3. Review of articles on criteria and indicators of the sustainable built environment by country

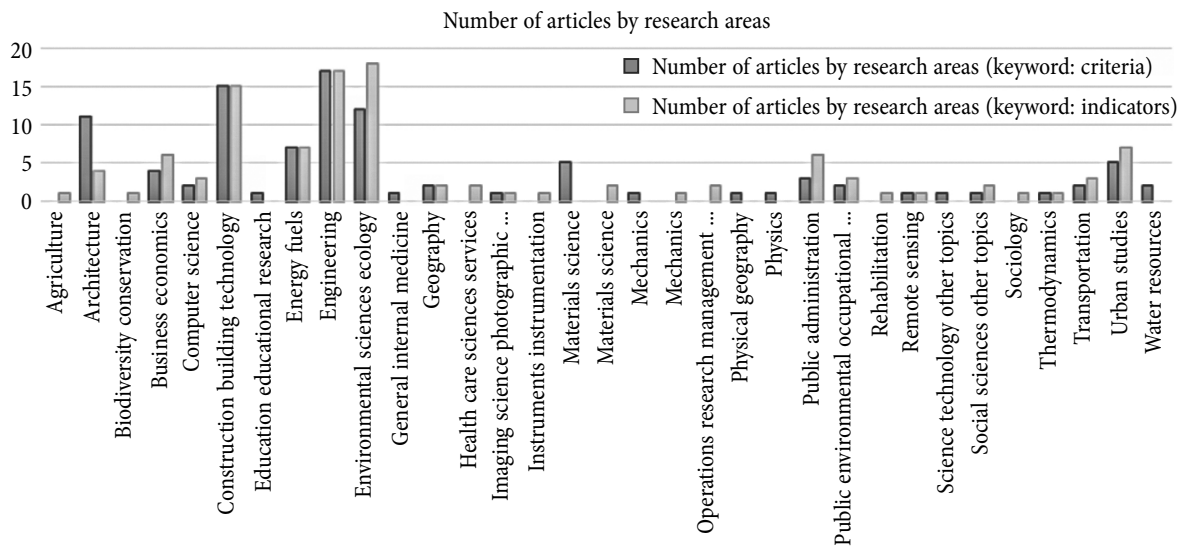

Fig. 4. Review of articles on criteria and indicators of the sustainable built environment by a research area 


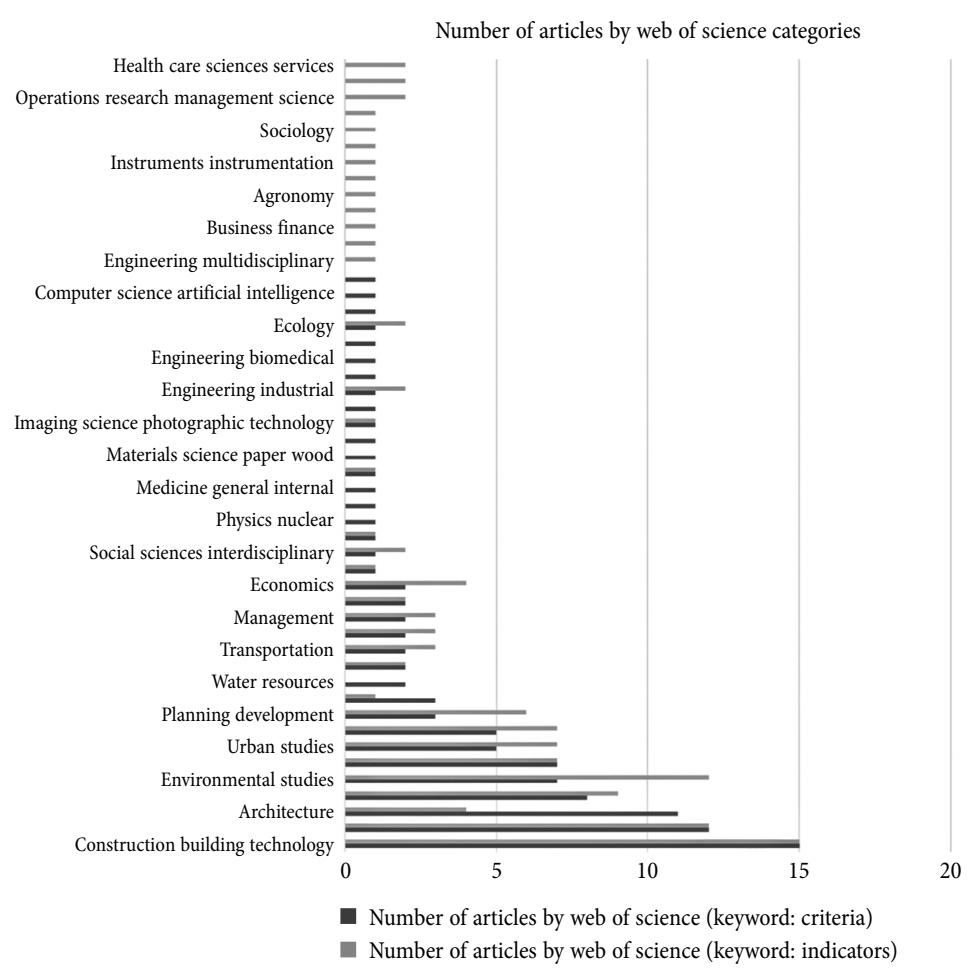

Fig. 5. Review of articles on criteria and indicators of the sustainable built environment by a research area

The key Web of Science categories, which also encompass research on the sustainable built environment, are: construction building technologies, environmental science and studies, and civil engineering (Fig. 5).

Based on the analysis of articles by the Web of Science categories, there are $11.37 \%$ of articles using the keyword "indicator" compared to those containing the keyword "criterion", or 123 and 103 articles, respectively. Due to this, the following three areas of application were selected for further analysis: environmental science, environmental studies, construction and building technology.

\section{Analysis of the sustainable built environment in three key Web of Science categories: environmental science, environmental studies, and construction and building technology}

The review of the sustainable built environment in areas of environmental science, environmental studies, and construction and building technology covered 31 articles and reviews selected from the Web of Science Core Collection database.

The term sustainable development can be described as the enhancement of the quality of life that allows people to live in a healthy environment and improves social, economic and environmental conditions for the present and future generations. The improvement of social, economic and environmental indicators of the sustainable development draws attention to the construction industry, which is a globally emerging sector and a highly active industry (Ortiz et al. 2009). For this reason, Ortiz et al. (2009) undertook a review of the life cycle analysis (LCA) because of its broad international acceptance as a means to the improvement of environmental processes and services as well as its use in the creation of measures preventing adverse environmental impacts and continuously enhancing the quality of life in a healthy environment. According to Lowe et al. (2015), planning healthy, liveable and sustainable communities epitomizes the crucial nexus between public health, urban planning and the environment with potential co-benefits across all sectors.

In their research, Ho et al. (2008) also underlined the importance of healthy and safe environment. They looked at the relationship between development of a healthy and safe environment and the density of multistorey residential buildings in Hong Kong. Based on the cost-effective assessment schemes developed by Ho et al. (2008), which are used to evaluate the health and safety performance, they found considerable variations in health and safety conditions across buildings located within a single district. Most of the variations in the health and safety conditions of the buildings were 
attributed to differences in building management systems rather than to the building design.

Healthy environment of occupants in sustainable homes and buildings was analysed by $\mathrm{Yu}$ and Kim (2011) who observed the indoor air quality (IAQ). The researchers made a review of Building Environmental Assessment Schemes for Rating of IAQ in Sustainable Buildings. According to the authors, there should be an IAQ management plan for any housing or building developed, which should include a certification of the IAQ of the living spaces prior to their occupancy. Additionally, low-emitting materials should be used in new buildings.

Foreign authors designed various frameworks for the assessment of the sustainable built environment (Björnberg 2009; Bentivegna et al. 2002; Morrissey et al. 2012; Siew 2015). For example, Björnberg (2009) developed a conceptual framework for the assessment of environmental policy goals, which was empirically tested against the Swedish environmental quality objective "a good built environment". The researcher uses a new term "a good built environment", which is defined as 25 indicators focusing on different aspects of the urban environment, such as the level of benzene in the air, the number of homes with dampness and mould, and the level of radon in apartment buildings. Bentivegna et al. (2002) suggested the BEQUEST framework for structuring information on the sustainable urban development. This framework provides a unique integrated representation of the scope and extent of the subject that links together socio-economic and technical dimensions as well as planning, property, design and construction interests in time and space. The Strategic Project Appraisal framework was developed by Morrissey et al. 2012, while Siew 2015 proposed an alternative framework named the Green Building Fund for the assessment of sustainable building funds.

Researchers Perales-Momparler et al. (2015), Reiter and Marique (2012), and Adrian et al. (2013) suggested methodologies for assessment of the sustainable built environment. Perales-Momparler et al. (2015) present an innovative methodology for approaching the concept of the regenerative urban built environment by focusing on municipal infrastructure systems or sub-systems with a holistic view. Reiter and Marique (2012) proposed a methodology for assessing residential energy uses for buildings and transport at a city scale. This method is based on the use of the geo- graphic information system (GIS) tools combined with a statistical treatment of urban and transport criteria. The methodology allows modelling the use of building and transport energy at a city scale, as well as considering the possible evolution of the city energy consumption and simulating the effects of some strategies of urban renewal. In the area of construction and building technologies, Adrian et al. (2013) analysed the envelope performance of commercial office buildings in Singapore. The researchers suggested a methodology for evaluating the building performance of offices whilst taking into account its surrounding morphology, using GIS as a platform for the integration with an urban climatic assessment tool.

The construction industry, therefore, faces certain pressures to increase the sustainability of its practices reflected in the development of stringent regulations and environmental assessment methods, designed to mitigate such negative impacts (Alyami et al. 2015). Alyami et al. (2015) proposed to customize an adapted weighting system that prioritizes the categories of the Saudi environmental assessment method (SEAM). The research methodology involves the use of the analytic hierarchy process (AHP). The results revealed that well-known environmental assessment methods are not fully applicable to the built environment of Saudi Arabia, as reflected in the resulting categories, criteria and weighting system of the SEAM. ALwaer and Clements-Croome (2010) also suggested reaching for the consensus-based model (Sustainable Built Environment Tool- SuBETool), which uses analytical hierarchical process (AHP) for multi-criteria decisionmaking. Their research demonstrated that the benefit of the new proposed model (SuBETool) is a 'tool' for a 'comparative' measurement rather than absolute measurement. It has the potential to draw useful lessons from current sustainability assessment methods that could be used for strategically planned future of sustainable intelligent buildings in order to improve a building's performance and to deliver objective outcomes.

Ding et al. (2015) developed the model referred to as the Trinity of Cities' Sustainability from Spatial, Logical and Time Dimensions (TCS-SLTD), which is a useful tool for guiding the process for the selection of Sustainable Development Indicators, and provides a conceptual framework for the holistic assessment of the sustainability of a city growth and expansion in developing countries. The model can assist urban 
planners and policy makers of developing countries in integrated assessment of city sustainability, and in the formulation of pragmatic and focused policies to shift cities towards more regenerative and sustainable development trajectories (Ding et al. 2015). Conte and Monno (2012) also developed an integrated building urban evaluation model based on the urban matrix, which is a conceptualisation of the built environment as a socioecological system. This model, as well as the one developed by Ding et al. (2015), is also based on holistic approach. The model aims at evaluating the sustainability of a building considering it as an active entity contributing to the resilience of the urban matrix. Some holistic performance indicators are used for evaluating such contribution and expressing the reliability of a building. Models designed by other authors (Dur et al. 2014; Dizdaroglu 2015; Adrian et al. 2013) are presented in Table 2.
Within the period under analysis, many tools and assessment systems were developed (Ding et al. 2015; Kim, Todorovic 2013; Bourdic et al. 2012; Borzacchiello et al. 2010; Chen et al. 2010) for the analysis of the sustainable built environment. Bourdic et al. 2012 developed a system to improve the energy efficiency and environmental footprint of cities. However, most of these tools are based on the scale of the building (Bourdic et al. 2012). Most urban stakeholders are now convinced that the building scale approach is insufficient: the scale of analysis should evolve from the building to the neighbourhood, the district and the city. Gibberd (2015) developed the Built Environment Sustainability Tool (BEST). BEST facilitates the evaluation of options which may be considered for improving the sustainability capability of building-neighbourhood combinations. BEST also provides an alternative to other green building rating tool approaches.

Table 2. Summary of research on the sustainable built environment in three Web of Science categories: environmental science, environmental studies, and construction and building technology area

\begin{tabular}{|c|c|}
\hline Authors & Research/results \\
\hline \multicolumn{2}{|r|}{ Environmental science } \\
\hline Ding et al. 2015 & $\begin{array}{l}\text { The paper outlines an inclusive, causal framework for the assessment of the Sustainable Development, } \\
\text { entitled the Trinity of Cities' Sustainability from Spatial, Logical and Time Dimensions (TCS-SLTD). } \\
\text { The TCS-SLTD model is a useful tool for guiding the process of the selection of Sustainable Development } \\
\text { Indicators, and provides a conceptual framework for the holistic assessment of the sustainability of a city } \\
\text { growth and expansion in developing countries. }\end{array}$ \\
\hline $\begin{array}{l}\text { Perales- } \\
\text { Momparler } \\
\text { et al. } 2015\end{array}$ & $\begin{array}{l}\text { The article presents an innovative regenerative urban stormwater methodology for transition management } \\
\text { at a city level, containing two main enablers to overcome the barriers that drag out progress. }\end{array}$ \\
\hline $\begin{array}{l}\text { Bahadure, } \\
\text { Kotharkar } 2015\end{array}$ & $\begin{array}{l}\text { The authors assess the sustainability of the neighbourhoods with mixed land-use in the context of the } \\
\text { Nagpur city, India. The study revealed that neighbourhoods with high and moderate land-use mix are } \\
\text { sustainable with travel behaviour. }\end{array}$ \\
\hline $\begin{array}{l}\text { Alyami et al. } \\
2015\end{array}$ & $\begin{array}{l}\text { The authors developed a weighting system that prioritizes the categories of the Saudi environmental } \\
\text { assessment method (SEAM). The research methodology involves the use of the analytic hierarchy process } \\
\text { (AHP). }\end{array}$ \\
\hline $\begin{array}{l}\text { Rogers et al. } \\
2013\end{array}$ & $\begin{array}{l}\text { The paper presents the case study approach to examine the third pillar more comprehensively, and offers the } \\
\text { social capital as one measure of the social sustainability. Specifically, the social capital was used to measure } \\
\text { the social-environmental interface of communities. The positive correlation between aspects of the built } \\
\text { environment, specifically the walkability, and the social capital suggests that measuring the social aspect of } \\
\text { sustainability may be feasible, especially in the context of community development. }\end{array}$ \\
\hline Ioan, Ursu 2012 & $\begin{array}{l}\text { The article provides an analysis of strategies for maintaining the sustainable quality of life in environments } \\
\text { with air conditioning. }\end{array}$ \\
\hline $\begin{array}{l}\text { Klein-Banai, } \\
\text { Theis } 2011\end{array}$ & $\begin{array}{l}\text { The authors present an analysis of the ecological footprint of an urban university. A sensitivity analysis } \\
\text { to examine the effect of climate change events on the footprint indicated that if all other factors are held } \\
\text { constant, climate change increases the ecological footprint of the University of Illinois in Chicago. }\end{array}$ \\
\hline $\begin{array}{l}\text { Reiter, Marique } \\
2012\end{array}$ & $\begin{array}{l}\text { The authors proposed the methodology for assessing residential energy uses for buildings and transport } \\
\text { at the scale of a city. This method is based on the use of the geographic information system (GIS) tools, } \\
\text { combined with a statistical treatment of urban and transport criteria. }\end{array}$ \\
\hline $\begin{array}{l}\text { Monahan, } \\
\text { Powell 2011 }\end{array}$ & $\begin{array}{l}\text { The paper evaluates the energy use, consequential emissions of } \mathrm{CO} 2 \text {, and the annual running costs for a } \\
\text { case study comprising } 14 \text { newly constructed low energy affordable homes. Four different energy typologies } \\
\text { are compared: ground sourced heat pumps; active solar (thermal and photovoltaic); passive solar and } \\
\text { mechanical ventilation with heat recovery; conventional high-efficiency gas boiler. }\end{array}$ \\
\hline
\end{tabular}


Continue of Table 2

\begin{tabular}{|c|c|}
\hline Authors & Research/results \\
\hline Björnberg 2009 & $\begin{array}{l}\text { The author presents an analysis of "a good built environment". The objective of "a good built environment" } \\
\text { is evaluated by means of approximately } 25 \text { indicators focusing on different aspects of the urban } \\
\text { environment, such as the level of benzene in the air, the number of homes with damp and mould, and the } \\
\text { level of radon in apartment buildings. }\end{array}$ \\
\hline \multicolumn{2}{|r|}{ Environmental studies } \\
\hline Dizdaroglu 2015 & $\begin{array}{l}\text { The paper proposes a set of key micro-level urban ecosystem indicators for monitoring the sustainability } \\
\text { of residential developments. The proposed indicator framework measures the sustainability performance } \\
\text { of urban ecosystem in } 3 \text { main categories including natural environment, built environment, and socio- } \\
\text { economic environment which are made up of } 9 \text { sub-categories, consisting of } 23 \text { indicators. }\end{array}$ \\
\hline Lowe et al. 2015 & $\begin{array}{l}\text { The article gives an overview of liveability indicators used to date in Australia and internationally. Indicators } \\
\text { were measured at three scales: individual-level measures (e.g. perceptions of safety collected through } \\
\text { surveys); social or built environment-level measures (e.g. recorded crime rates or land use mix in a } \\
\text { particular area); or policy-level measures, which are used to collect information on urban policies or plans. }\end{array}$ \\
\hline Dur et al. 2014 & $\begin{array}{l}\text { The authors developed a spatial index by a number of indicators compiled from international studies and } \\
\text { trialled in Gold Coast, Queensland, Australia. The model has proved useful in demarcating areas where } \\
\text { a planning intervention is applicable, and in identifying the most suitable locations for future urban } \\
\text { development and plan amendments. } \\
\text { Researchers integrated variance-based sensitivity analysis with the spatial indexing method and discussed } \\
\text { the applicability of the model in other urban contexts. }\end{array}$ \\
\hline $\begin{array}{l}\text { Conte, Monno } \\
2012\end{array}$ & $\begin{array}{l}\text { The authors developed a cross-scale evaluation approach focusing on the reliability of sustainable building } \\
\text { design solutions for the context, in which the building is situated. An integrated building-urban evaluation } \\
\text { model is proposed based on the urban matrix, which is a conceptualisation of the built environment as a } \\
\text { social-ecological system. The model aims at evaluating the sustainability of a building considering it as an } \\
\text { active entity contributing to the resilience of the urban matrix. Some holistic performance indicators are } \\
\text { used for evaluating such contribution, thus expressing the building reliability. }\end{array}$ \\
\hline $\begin{array}{l}\text { Morrissey et al. } \\
2012\end{array}$ & $\begin{array}{l}\text { The article presents the developed framework for the Strategic Project Appraisal (SPA), grounded in } \\
\text { the theory of the Strategic Environmental Assessment (SEA). It can be used as a means for practically } \\
\text { appraising project impacts and alternatives in terms of quantified ecological limits. It addresses the } \\
\text { neglected topic of the metropolitan infrastructure as a means of delivering sustainability outcomes in the } \\
\text { urban context and, more broadly, seeks to open a debate on the potential for the SEA methodology to be } \\
\text { more extensively applied to address sustainability challenges in the built environment. Practically applied } \\
\text { and timed appropriately, the SPA framework can enable better decision-making and more efficient resource } \\
\text { allocation ensuring the development of a low-impact infrastructure. }\end{array}$ \\
\hline $\begin{array}{l}\text { Borzacchiello } \\
\text { et al. } 2010\end{array}$ & $\begin{array}{l}\text { The authors aimed at identifying the impact of differences in spatial accessibility on the development of } \\
\text { the built environment in cities. Using some simple accessibility indicators, the authors attempted to map } \\
\text { out quantitatively the detailed implications of accessibility conditions for built-up areas, on the basis of a } \\
25 \mathrm{x} 25 \mathrm{~m} \text { grid cell approach. The statistical tools used are the discriminant analysis and logistic regression, } \\
\text { followed by a GIS representation of the empirical results for four Dutch cities: Amsterdam, The Hague, } \\
\text { Rotterdam, and Utrecht. }\end{array}$ \\
\hline Lau, Ho 2011 & $\begin{array}{l}\text { Open Building as a sustainable approach to deal with the problems associated with the aging housing stock. } \\
\text { It is seldom applied in high-rise, densely populated built environment. Implementing Open Building using } \\
\text { flexible and green fittings remains a viable option that enables transformation in existing housing stock. }\end{array}$ \\
\hline \multicolumn{2}{|r|}{ Construction building technology } \\
\hline Siew 2015 & $\begin{array}{l}\text { The author proposed an alternative framework named the Green Building Fund that can be used for } \\
\text { the assessment of sustainable building funds. The framework will not only be useful for AusIndustry } \\
\text { (the funding body of the GBF) and other worldwide government departments responsible for awarding } \\
\text { green building funds but also for owners who are keen to strengthen their application by improving the } \\
\text { demonstration of project feasibility. }\end{array}$ \\
\hline $\begin{array}{l}\text { Rakhshan et al. } \\
2013\end{array}$ & $\begin{array}{l}\text { Evaluating the sustainability impact of the improved building insulation. The study shows that in the } \\
\text { particular case of the residential built environment of Dubai and the prevailing local electric power source } \\
\text { generation mechanisms, the environmental sustainability cost of adding the insulation levels required to } \\
\text { significantly mitigate transmission losses is small in comparison to the operational GHG emissions saved by } \\
\text { their application. }\end{array}$ \\
\hline Pawar et al. 2015 & $\begin{array}{l}\text { The authors describe a procedure devised using the Geographic Information System (GIS) to delineate } \\
\text { boundaries of zones, where any change in thermal comfort requirement indicates a corresponding change } \\
\text { in responsive building design strategies. }\end{array}$ \\
\hline
\end{tabular}


End of Table 2

\begin{tabular}{|c|c|}
\hline Authors & Research/results \\
\hline Gibberd 2015 & $\begin{array}{l}\text { The Built Environment Sustainability Tool (BEST) was developed as a way of assessing the sustainability } \\
\text { performance of built environments and identifying ways for improving them. }\end{array}$ \\
\hline $\begin{array}{l}\text { Adrian et al. } \\
2013\end{array}$ & $\begin{array}{l}\text { The authors present a methodology for evaluating the building performance of offices in Singapore whilst } \\
\text { taking into account its surrounding morphology, using GIS as a platform for integration with an urban } \\
\text { climatic assessment tool. }\end{array}$ \\
\hline $\begin{array}{l}\text { Kim, Todorovic } \\
2013\end{array}$ & $\begin{array}{l}\text { The article present the complex system of sustainability's hierarchic character, criteria and indicators. A } \\
\text { scheme of the structure and spatial-temporal vision of the Global sustainable development is presented, } \\
\text { showing that the approach to the global sustainable development can be reliable only if it is based on a } \\
\text { system of real human and ethical values applicable to every social, cultural and economic situation. }\end{array}$ \\
\hline $\begin{array}{l}\text { Bourdic et al. } \\
2012\end{array}$ & $\begin{array}{l}\text { An innovative system of indicators is presented that meets the need for multi-scale and cross-scale } \\
\text { indicators and encompasses the intrinsic complexity of the city. Based on a morphologic approach, new } \\
\text { mathematical formulas are used to generate urban sustainability indicators. }\end{array}$ \\
\hline $\begin{array}{l}\text { ALwaer, } \\
\text { Clements- } \\
\text { Croome } 2010\end{array}$ & $\begin{array}{l}\text { The authors developed the Consensus-based model (Sustainable Built Environment Tool - SuBETool). } \\
\text { The benefit of the new proposed model (SuBETool) is a 'tool' for a 'comparative' rather than an absolute } \\
\text { measurement. }\end{array}$ \\
\hline Ortiz et al. 2009 & $\begin{array}{l}\text { The review details LCA concepts and focuses on the LCA methodology and tools employed in the built } \\
\text { environment. The authors outline and discuss the differences between the LCA of building materials } \\
\text { and components combinations versus the LCA of the full building life cycle. The review can be used } \\
\text { by stakeholders as an important reference on LCA including up-to-date literature on approaches and } \\
\text { methodologies to preserve the environment and, therefore, achieve the sustainable development in both } \\
\text { developed and developing countries. }\end{array}$ \\
\hline Ho et al. 2008 & $\begin{array}{l}\text { The authors conducted a survey of the health and safety performance of apartment buildings in a densely } \\
\text { populated city of Hong Kong, using a simplified assessment scheme. }\end{array}$ \\
\hline $\begin{array}{l}\text { Bentivegna et al. } \\
2002\end{array}$ & $\begin{array}{l}\text { The BEQUEST framework for structuring information on sustainable urban development was developed } \\
\text { and provides a unique, integrated representation of the scope and extent of the subject that links together } \\
\text { socio-economic and technical dimensions as well as planning, property, design and construction interests, } \\
\text { in time and space. }\end{array}$ \\
\hline Yu, Kim 2011 & $\begin{array}{l}\text { The review presents the Building Environmental Assessment Schemes for Rating of IAQ in Sustainable } \\
\text { Buildings. The paper illustrates the criteria included in BREEAM, LEED and HK BEAM rating systems for } \\
\text { assessment of indoor air quality (IAQ). }\end{array}$ \\
\hline Chen et al. 2010 & $\begin{array}{l}\text { The authors present the construction method selection for concrete buildings. This paper lays the } \\
\text { groundwork for automated tools to help make project-level decisions regarding prefabrication strategies } \\
\text { and facilitates the achievement of a healthy built environment, and thus the likelihood of sustainable } \\
\text { construction. }\end{array}$ \\
\hline Buegl et al. 2009 & $\begin{array}{l}\text { An investigation was conducted into which sustainability criteria institutional real estate investors and real } \\
\text { estate fund (REF) suppliers consider important for the market success of sustainable property (real estate) } \\
\text { funds (S-REFs) and what is their market acceptance. }\end{array}$ \\
\hline
\end{tabular}

Those approaches have a strong focus on the performance of the building itself and a reduction in negative environmental impacts (doing less harm) (Gibberd 2015).

A broader review of sustainable built environment applications in the areas of the environmental science, environmental studies, and construction and building technology is presented in Table 2.

The review of foreign literature has revealed that the sustainable development is not only perceived as an integration of economic, social and environmental criteria but also as the creation of healthy and safe environment for the community. The integrated multicriteria methods (such as AHP, Fuzzy) can be used for holistic assessment of multi-criteria decision-making related to the sustainable built environment.

\section{Conclusions}

1. In achieving the sustainable development, the building industry is a key player, because the built environment is responsible for significant use of the final energy (62\%) and is a major source of greenhouse gas emissions (55\%).

2. While aiming to develop a healthy and safe environment, based on the holistic approach in the face of the urbanisation issues, it is especially important to focus on the sustainable development with the help of the most up-to-date methodologies, systems and solutions offered by foreign researchers.

3. The analysis of articles according to years of publication (1998-2015) revealed that, compared to 2014, 2015 saw 57.13\% more articles on criteria of 
the sustainable built environment and $66.67 \%$ more articles on indicators of the sustainable built environment. Most articles were published in England (containing the keyword "criterion") and the USA (containing the keyword "indicator"). According to research areas, the majority of research efforts take place in areas of construction and building technologies, engineering and environmental science ecology. The key categories of Web of Science, which encompass the research on the sustainable built environment, cover construction and building technologies, environmental science and studies, and civil engineering.

4. The review of foreign literature has revealed that the sustainable development is not only perceived as an integration of economic, social and environmental criteria but also as the creation of healthy and safe environment for the community. The integrated multi-criteria methods (such as AHP, Fuzzy) can be used for holistic assessment of multi-criteria decision-making related to the sustainable built environment.

5. Sustainable built environment research is the subject of this article, while various methods of MCDA are treated as a tool. The benefits of resorting to these methods are evident. The reader must ascertain that sustainable development belongs to the area of multi-criteria problems, and today it has become an imperative in designing issues at the interface of the human being - ecology - economy.

\section{References}

Adrian, C. Z. M.; Hien, W. N.; Marcel, I.; Kardinal, J. S. 2013. Predicting the envelope performance of commercial office buildings in Singapore, Energy and Buildings 66: 66-76. http://dx.doi.org/10.1016/j.enbuild.2013.07.008

ALwaer, H.; Clements-Croome, D. J. 2010. Key performance indicators (KPIs) and priority setting in using the multi-attribute approach for assessing sustainable intelligent buildings, Building and Environment 45(5): 799-807.

Alyami, S. H.; Rezgui, Y.; Kwan, A. 2015. The development of sustainable assessment method for Saudi Arabia built environment: weighting system, Sustainability Science 10(1): 167-178. http://dx.doi.org/10.1007/s11625-014-0252-x

Anderson, J. E.; Wulfhorst, G.; Lang, W. 2015. Energy analysis of the built environment - A review and outlook, Renewable and Sustainable Energy Reviews, 44: 149-158. http://dx.doi.org/10.1016/j.rser.2014.12.027

Antucheviciene, J.; Kala, Z.; Marzouk, M.; Vaidogas, E. R. (Eds.) 2015. Decision making methods and applications in civil engineering. Mathematical Problems in Engineering. Cairo: Hindawi Publishing Corporation.
Bahadure, S.; Kotharkar, R. 2015. Assessing sustainability of mixed use neighbourhoods through residents' travel behaviour and perception: the case of Nagpur, India, Sustainability 7(9): 12164-12189. http://dx.doi.org/10.3390/su70912164

Bentivegna, V.; Curwell, S.; Deakin, M.; Lombardi, P.; Mitchell, G.; Nijkamp, P. 2002. A vision and methodology for integrated sustainable urban development: BEQUEST, Building Research \& Information 30(2): 83-94.

http://dx.doi.org/10.1080/096132102753436468

Björnberg, K. E. 2009. Rational goals for the urban environment: A Swedish example, European Planning Studies 17(7): 1007-1027. http://dx.doi.org/10.1080/09654310902949570

Borzacchiello, M. T.; Nijkamp, P.; Koomen, E. 2010. Accessibility and urban development: a grid-based comparative statistical analysis of Dutch cities, Environment and Planning B-Planning \& Design 37(1): 148-169. http://dx.doi.org/10.1068/b34126

Bourdic, L.; Salat, S.; Nowacki, C. 2012. Assessing cities: a new system of cross-scale spatial indicators, Building Research \& Information 40(5): 592-605. http://dx.doi.org/10.1080/09613218.2012.703488

Buegl, R.; Leimgruber, C.; Hueni, G. R.; Scholz, R. W. 2009. Sustainable property funds: financial stakeholders' views on sustainability criteria and market acceptance, Building Research \& Information 37(3): 246-263.

http://dx.doi.org/10.1080/09613210902843494

Chen, Y.; Okudan, G. E.; Riley, D. R. 2010. Sustainable performance criteria for construction method selection in concrete buildings, Automation in Construction 19(2): 235-244. http://dx.doi.org/10.1016/j.autcon.2009.10.004

Conte, E.; Monno, V. 2012. Beyond the buildingcentric approach: A vision for an integrated evaluation of sustainable buildings, Environmental Impact Assessment Review 34: 31-40. http://dx.doi.org/10.1016/j.eiar.2011.12.003

De Meester, B.; Dewull, J.; Verbeke, S.; Janssens, A.; Van Langenhove, H. 2009. Energetic life-cycle assessment (ELCA), Building and Environment 44(1): 11-17. http://dx.doi.org/10.1016/j.buildenv.2008.01.004

Ding, X.; Zhong, W.; Shearmur, R. S.; Zhang, X.; Huisingh, D. 2015. An inclusive model for assessing the sustainability of cities in developing countries - Trinity of Cities' Sustainability from Spatial, Logical and Time Dimensions (TCS-SLTD), Journal of Cleaner Production 109: 62-75. http://dx.doi.org/10.1016/j.jclepro.2015.06.140

Dizdaroglu, D. 2015. Developing micro-level urban ecosystem indicators for sustainability assessment, Environmental Impact Assessment Review 54: 119-124. http://dx.doi.org/10.1016/j.eiar.2015.06.004

Dur, F.; Yigitcanlar, T.; Bunker, J. 2014. A spatial-indexing model for measuring neighbourhood-level land-use and transport integration, Environment and Planning B-Planning \& Design 41(5): 792-812. http://dx.doi.org/10.1068/b39028

Dziadosz, A.; Kapliński, O.; Rejment M. (2015) Łączne koszty budynku w cyklu życia inwestycji budowlanej [Total costs of a building in the life cycle of a construction project], in: A. Podchorecki (Ed.) Wybrane problemy budownictwa, Uniwersytet Technologiczno-Przyrodniczy in Bydgoszcz, 127-134.

Gibberd, J. 2015. Measuring capability for sustainability: the built environment sustainability tool (BEST), Building Research \& Information 43(1): 49-61.

http://dx.doi.org/10.1080/09613218.2014.930257 
Ho, D. C-W.; Chau, K-W.; Cheung, A. K-C.; Yau, Y.; Wong, S-K.; Leung, H-F.; Lau, S. S-Y.; Wong, Q-S. 2008. A survey of the health and safety conditions of apartment buildings in Hong Kong, Building and Environment 43(5): 764-775. http://dx.doi.org/10.1016/j.buildenv.2007.01.035

Ioan, C. C.; Ursu, C. 2012. Real needs and preventive strategies for maintaining sustainable quality of life in environments with air conditioning, Environmental Engineering and Management Journal 1(4):879-884

Kaklauskas, A.; Zavadskas, E. K. (Eds.) 2015. Multiple criteria analysis of the life cycle of the built environment. Vilnius: Technika. 448 p.

Kaklauskas, A.; Zavadskas, E. K.; Dargis, R.; Bardauskienė, D. (Eds.) 2015. Sustainable development of real estate. Vilnius: Technika. 512 p. http://dx.doi.org/10.3846/2336-M

Kaklauskas, A.; Zavadskas, E.; Bardauskiene, D.; Dargis, P. (Eds). 2014. Garmonichnoje razvitije nedvizhimogo imushchestva. Vilnius: Technika. 424 p.

Kaklauskas, A.; Zavadskas, E. K. 2012. Biometricheskaja $i$ intellektual'naja podderzhka reshenij. Vilnius: Technika. 344 p.

Kaplinski O.; Peldschus F.; Tupenaite L. 2014. Development of MCDM Methods - in honour of Professor Edmundas Kazimieras Zavadskas on the occasion of his 70th birthday, International Journal of Computers Communications \& Control 9(3): 305-312. http://dx.doi.org/10.15837/ijccc.2014.3.1084

Kapliński, O.; Tupenaite, L. 2011. Review of the multiple criteria decision making methods, intelligent and biometric systems applied in modern construction economics, Transformations in Business \& Economics 10(1): 166-181.

Kim, J. T.; Todorovic, M. S. 2013. Towards sustainability index for healthy buildings - Via intrinsic thermodynamics, green accounting and harmony, Energy and Buildings 62: 627-637. http://dx.doi.org/10.1016/j.enbuild.2013.03.009

Klein-Banai, C.; Theis, T. L. 2011. An urban university's ecological footprint and the effect of climate change, Ecological Indicators 11(3): 857-860.

http://dx.doi.org/10.1016/j.ecolind.2010.11.002

Lau, W. K. L.; Ho, D. C. W. 2011. Open building implementation in high-rise residential buildings in Hong Kong, Open House International 36(1): 25-34.

Lowe, M.; Whitzman, C.; Badland, H.; Davern, M.; Aye, L.; Hes, D.; Butterworth, I.; Giles-Corti, G. 2015. Planning healthy, liveable and sustainable cities: how can indicators inform policy?, Urban Policy and Research 33(2): 131-144. http://dx.doi.org/10.1080/08111146.2014.1002606

Mardani, A.; Jusoh, A.; Zavadskas, E. K.; Cavallaro, F.; Khalifah, Z. 2015. Sustainable and renewable energy: an overview of the application of multiple criteria decision making techniques and approaches, Sustainability 7(10): 13947-13984. http://dx.doi.org/10.3390/su71013947

Monahan, J.; Powell, J. C. 2011. A comparison of the energy and carbon implications of new systems of energy provision in new build housing in the UK, Energy Policy 39(1): 290-298. http://dx.doi.org/10.1016/j.enpol.2010.09.041

Morrissey, J.; Iyer-Raniga, U.; McLaughlin, P.; Mills, A. 2012. A strategic project appraisal framework for ecologically sustainable urban infrastructure, Environmental Impact Assessment Review 33(1): 55-65.

http://dx.doi.org/10.1016/j.eiar.2011.10.005
Ortiz, O.; Castells, F.; Sonnemann, G. 2009. Sustainability in the construction industry: A review of recent developments based on LCA, Construction and Building Materials 23(1): 28-39. http://dx.doi.org/10.1016/j.conbuildmat.2007.11.012

Pawar, A. S.; Mukherjee, M.; Shankar, R. 2015. Thermal comfort design zone delineation for India using GIS, Building and Environment 87: 193-206.

http://dx.doi.org/10.1016/j.buildenv.2015.01.009

Perales-Momparler, S.; Andrés-Doménech, I.; Andreu, J.; Escuder-Bueno, I. 2015. A regenerative urban stormwater management methodology: the journey of a Mediterranean city, Journal of Cleaner Production 109: 174-189. http://dx.doi.org/10.1016/j.jclepro.2015.02.039

Rakhshan, K.; Friess, W. A.; Tajerzadeh, A. 2013. Evaluating the sustainability impact of improved building insulation: A case study in the Dubai residential built environment, Building and Environment 67: 105-110. http://dx.doi.org/10.1016/j.buildenv.2013.05.010

Reiter, S.; Marique, A-F. 2012. Toward low energy cities, Journal of Industrial Ecology 16(6): 829-838. http://dx.doi.org/10.1111/j.1530-9290.2012.00533.x

Rogers, A. H.; Gardner, K. H.; Carlson, C. H. 2013. Social capital and walkability as social aspects of sustainability, Sustainability 5(8): 3473-3483.

Siew, R. Y. J. 2015. Alternative framework for assessing sustainable building funds: green building fund, Building Research \& Information 43(2): 160-169.

http://dx.doi.org/10.1080/09613218.2014.936170

Srinivasan, S.; O‘Fallon, L. R.; Dearry, A. 2003. Creating healthy communities, healthy homes, healthy people: initiating a research agenda on the built environment and public health, American Journal of Public Health 93(9): 1446-1450.

http://dx.doi.org/10.2105/AJPH.93.9.1446

Stanhope, M. 2012. Public health nursing: population-centered health care in the community. Mosby. 8 ed. 1128 p.

Štreimikienè, D.; Čiegis, R.; Bankauskaitè-Sereikienè, G.; Slavickienè, A.; Šarkiūnaitè, I.; Mikalauskienè, A.; Lapėnienè, D.; Kiaušienė, I. 2014. Darnus vystymasis: teorija ir praktika [Sustainable development: theory and practice], [online], [cited 14 March 2016]. Available from Internet: http://www.khf.vu.lt/dokumentai/failai/soctyri/Darnus_ Lietuvos_vystymasis_2014.pdf

Viteikiene, M.; Zavadskas, E. K. 2007. Evaluating the sustainability of Vilnius city residential areas, Journal of Civil Engineering and Management 8(2): 149-155.

Yu, C. W. F.; Kim, J. T. 2011. Building environmental assessment schemes for rating of IAQ in sustainable buildings, Indoor and Built Environment 20(1): 5-15. http://dx.doi.org/10.1177/1420326X10397780

Zavadskas, E. K.; Antuchevičienè, J.: Kaplinski, O. 2015a. Multicriteria decision making in civil engineering, Part 1 - A state-of-the-art survey, Engineering Structures and Technologies $7(3)$ : 103-113.

http://dx.doi.org/10.3846/2029882X.2015.1143204

Zavadskas, E. K.; Antuchevičienė, J.: Kaplinski, O. 2015b. Multicriteria decision making in civil engineering, Part 2 - Applications, Engineering Structures and Technologies 7(4): 151-167. http://dx.doi.org/10.3846/2029882X.2016.1139664

Zavadskas, E. K.; Antucheviciente, J.; Turskis, Z.; Adeli, H. 2016. Hybrid multiple-criteria decision-making methods: 
A review of applications in engineering, Scientia Iranica. Transactions A: Civil Engineering 23(1): 1-20. Amsterdam: Elsevier Science BV. ISSN 1026-3098.

Zavadskas, E. K.; Turskis, Z.; Kildienè, S. 2014. State of art surveys of overviews on MCDM/MADM methods, Technological and Economic Development of Economy 20(1): 165-179. http://dx.doi.org/10.3846/20294913.2014.892037

Zavadskas, E. K.; Viteikienè, M.; Šaparauskas, J. 2007. Sustainable development assessment of cities and their residential districts, Ekologija 53: 49-54.
Zavadskas, E.; Antucheviciene, J. 2006. Development of an indicator model and ranking of sustainable revitalization alternatives of derelict property: a Lithuanian case study, Sustainable Development 14(5): 287-299. http://dx.doi.org/10.1002/sd.285

Ieva UBARTE is a PhD student of Civil Engineering at Vilnius Gediminas Technical University. She is a Junior Researcher at the Research Institute of Smart Building Technologies. Research interests: sustainable built environment, life cycle, safe and healthy house, intelligent decision support systems.

Oleg KAPLIŃSKI is Professor of CE at Faculty of Architecture (IAP), Poznan University of Technology, Poznan, Poland. He lectures in economics and organization of the investment process, as well as theory and principles of work places design. The author of 240 publications. Doctor Honoris Causa of VGTU (1996). Member of the CE Committee of the Polish Academy of Sciences. His current research focuses on: integral management, integral design, risk management, theory of decision making and research methods in CE and architecture. 